Supporting Information for:

\title{
Controlling Ligand Coordination Spheres and Cluster Fusion in Superatoms
}

Douglas A. Reed, Taylor J. Hochuli, Natalia A. Gadjieva, Shoushou He, Ren A. Wiscons, Amymarie K. Bartholomew, Anouck M. Champsaur, Michael L. Steigerwald, ${ }^{*}$ Xavier Roy,* and Colin Nuckolls*

Columbia University, Department of Chemistry, New York, NY 10027, United States

\section{Experimental}

General considerations. All synthetic procedures were conducted under an inert $\mathrm{N}_{2}$ atmosphere in a glovebox or using standard Schlenk techniques. Solvents were purchased from Sigma-Aldrich and dried with an alumina column or $3-\AA$ molecular sieves prior to use. Ferrocenium hexafluorophosphate, tetracyanoquinodimethane (TCNQ), (trimethylsilyl)diazomethane solution, tetrabutylammonium cyanide, 2,6-dimethylphenyl isocyanide, and tetrabutylammonium hexafluorophosphate were purchased from Sigma-Aldrich and used as received. The starting materials $\quad\left[\right.$ trans $\left.-\mathrm{Co}_{6} \mathrm{Se}_{8}(\mathrm{CO})_{2}\left(\mathrm{PEt}_{3}\right)_{4}\right] \quad$ (2), $\quad\left[\right.$ cis $\left.-\mathrm{Co}_{6} \mathrm{Se}_{8}(\mathrm{CO})_{2}\left(\mathrm{PEt}_{3}\right)_{4}\right] \quad$ (3), $\left[\mathrm{Co}_{6} \mathrm{Se}_{8}\left(\mathrm{C}(\mathrm{H}) \mathrm{SiMe}_{3}\right)\left(\mathrm{PEt}_{3}\right)_{5}\right](4)$, and $\mathrm{PEt}_{2}\left(p-\mathrm{C}_{6} \mathrm{H}_{4} \mathrm{SMe}\right)$ were prepared according to previously published procedures. ${ }^{1,2,3}{ }^{1} \mathrm{H}$ nuclear magnetic resonance (NMR) measurements were carried out on Bruker DRX400 (400 MHz) or Avance III $500(500 \mathrm{MHz})$ spectrometers and referenced to residual protons in the NMR solvent $\left(\mathrm{C}_{6} \mathrm{D}_{6}, \delta=7.16\right)$. Infrared (IR) spectra were collected on a Perkin Elmer Spectrum400 FTIR spectrometer with a PIKE ATR attachment. The blue light source for all procedures was a Kessil PR160-456nm lamp.

Synthesis of $\left[\right.$ trans-Co6 $\left.\mathrm{Se}_{8}\left(\mathbf{C}(\mathrm{H}) \mathrm{SiMe}_{3}\right)_{2}\left(\mathrm{PEt}_{3}\right)_{4}\right]$ (5). The compound $\left[\right.$ trans $\left.-\mathrm{Co}_{6} \mathrm{Se}_{8}(\mathrm{CO})_{2}\left(\mathrm{PEt}_{3}\right)_{4}\right]$ (2) $(50 \mathrm{mg}, 0.033 \mathrm{mmol}, 1 \mathrm{eq})$ was dissolved in tetrahydrofuran and cooled to $-35{ }^{\circ} \mathrm{C}$. Trimethylsilyl diazomethane solution $(2.0 \mathrm{M}$ in hexanes, $70 \mu \mathrm{L}, 0.14 \mathrm{mmol}, 4.2 \mathrm{eq})$ was added, and the solution was warmed to $0{ }^{\circ} \mathrm{C}$ while stirring under blue light irradiation for 3 hours. The solvent was then removed in vacuo, and the product was extracted with hexanes $(3 \times 2 \mathrm{~mL})$. The solvent was removed in vacuo to afford the product $\left[\right.$ trans $\left.-\mathrm{Co}_{6} \mathrm{Se}_{8}\left(\mathrm{C}(\mathrm{H}) \mathrm{SiMe}_{3}\right)_{2}\left(\mathrm{PEt}_{3}\right)_{4}\right](5)$ as a black powder (35 mg, 64\%). Dark crystals suitable for X-ray diffraction were grown from a concentrated benzene solution.

${ }^{1} \mathrm{H}$ NMR (400 MHz, $\left.\mathrm{C}_{6} \mathrm{D}_{6}, 298 \mathrm{~K}\right): \delta=5.41(\mathrm{~s}, 2 \mathrm{H}), 1.92(\mathrm{~m}, 24 \mathrm{H}), 1.12(\mathrm{~m}, 32 \mathrm{H}), 0.22(\mathrm{~s}, 18 \mathrm{H})$ ppm.

Synthesis of $\left[\right.$ trans- $\left.\mathrm{Co}_{6} \mathrm{Se}_{8}\left(\mathrm{C}(\mathrm{H}) \mathrm{SiMe}_{3}\right)(\mathrm{CO})\left(\mathrm{PEt}_{3}\right)_{4}\right] \quad(6)$. The compound [trans$\left.\mathrm{Co}_{6} \mathrm{Se}_{8}(\mathrm{CO})_{2}\left(\mathrm{PEt}_{3}\right)_{4}\right]$ (2) (50 mg, $\left.0.033 \mathrm{mmol}, 1 \mathrm{eq}\right)$ was dissolved in tetrahydrofuran and cooled to $-35^{\circ} \mathrm{C}$. Trimethylsilyl diazomethane solution $(2.0 \mathrm{M}$ in hexanes, $20 \mu \mathrm{L}, 0.040 \mathrm{mmol}, 1.2 \mathrm{eq})$ was added, and the solution was warmed to $0{ }^{\circ} \mathrm{C}$ while stirring under blue light irradiation for 3 hours. The solvent was then removed in vacuo, and the product was extracted with hexanes $(3 \times 2$ $\mathrm{mL}$ ). The solvent was removed in vacuo to afford the product [trans$\left.\mathrm{Co}_{6} \mathrm{Se}_{8}\left(\mathrm{C}(\mathrm{H}) \mathrm{SiMe}_{3}\right)(\mathrm{CO})\left(\mathrm{PEt}_{3}\right)_{4}\right](6)$ as a black powder $(25 \mathrm{mg}, 48 \%)$. We note that nearly all cluster material that remains after the hexane extraction step is unreacted starting material $\mathbf{2}$ that 
can be isolated in high purity by triturating with acetonitrile $(2 \times 2 \mathrm{~mL})$, allowing for recovery and reuse in different reactions.

${ }^{1} \mathrm{H}$ NMR (400 MHz, C $\left.6 \mathrm{D}_{6}, 298 \mathrm{~K}\right): \delta=6.57(\mathrm{~s}, 1 \mathrm{H}), 1.74(\mathrm{~m}, 24 \mathrm{H}), 0.99(\mathrm{~m}, 36 \mathrm{H}), 0.37(\mathrm{~s}, 9 \mathrm{H})$ ppm.

IR: $1969 \mathrm{~cm}^{-1}\left(v_{\mathrm{CO}}\right)$

Synthesis of $\left[\mathrm{Co}_{6} \mathrm{Se}_{8}\left(\mathrm{C}_{5} \mathrm{H}_{5} \mathbf{N}\right)\left(\mathrm{PEt}_{3}\right)_{5}\right]$ (8). The compound $\left[\mathrm{Co}_{6} \mathrm{Se}_{8}\left(\mathrm{C}(\mathrm{H}) \mathrm{SiMe}_{3}\right)\left(\mathrm{PEt}_{3}\right)_{5}\right]$ (4) (20 $\mathrm{mg}, 0.012 \mathrm{mmol})$ was dissolved in pyridine $(1 \mathrm{~mL})$ to afford a dark red solution. Dark block-like crystals of $\left[\mathrm{Co}_{6} \mathrm{Se}_{8}\left(\mathrm{C}_{5} \mathrm{H}_{5} \mathrm{~N}\right)\left(\mathrm{PEt}_{3}\right)_{5}\right]$ (8) suitable for X-ray diffraction were grown from a concentrated pyridine solution. Due to the instability of this compound upon removing solvent, this cluster was not isolated and a yield was not obtained.

Synthesis of $\left[\mathrm{Co}_{6} \mathrm{Se}_{8}\left(\mathrm{CNC}_{6} \mathrm{H}_{3} \mathrm{Me}_{2}\right)\left(\mathrm{PEt}_{3}\right)_{5}\right]$ (9). To a solution of $\left[\mathrm{Co}_{6} \mathrm{Se}_{8}\left(\mathrm{C}(\mathrm{H}) \mathrm{SiMe}_{3}\right)\left(\mathrm{PEt}_{3}\right)_{5}\right]$ (4) $(10 \mathrm{mg}, 0.006 \mathrm{mmol}, 1 \mathrm{eq})$ dissolved in toluene $(2 \mathrm{~mL})$ was added a solution of 2,6-dimethylphenyl isocyanide $(1.2 \mathrm{mg}, 0.009 \mathrm{mmol}, 1.5 \mathrm{eq})$ in toluene $(2 \mathrm{~mL})$. The solution was stirred at room temperature for 1 hour. The solvent was removed in vacuo, and the resulting powder was triturated with acetonitrile $(2 \times 2 \mathrm{~mL})$ to afford the product $\left[\mathrm{Co}_{6} \mathrm{Se}_{8}\left(\mathrm{CNC}_{6} \mathrm{H}_{3} \mathrm{Me}_{2}\right)\left(\mathrm{PEt}_{3}\right)_{5}\right]$ (9) as a black powder $(9 \mathrm{mg}, 88 \%)$. Spectral data were consistent with previous reports. ${ }^{1}$

Synthesis of $\left[\mathbf{N B u}_{4}\right]\left[\mathrm{Co}_{6} \mathrm{Se}_{8}(\mathbf{C N})\left(\mathrm{PEt}_{3}\right)_{5}\right]$ (10). To a solution of $\left[\mathrm{Co}_{6} \mathrm{Se}_{8}\left(\mathrm{C}(\mathrm{H}) \mathrm{SiMe}_{3}\right)\left(\mathrm{PEt}_{3}\right)_{5}\right]$ (4) (10 mg, $0.006 \mathrm{mmol}, 1 \mathrm{eq})$ dissolved in benzene $(2 \mathrm{~mL})$ was added a solution of tetrabutylammonium cyanide $(2.4 \mathrm{mg}, 0.009 \mathrm{mmol}, 1.5 \mathrm{eq})$ in toluene $(2 \mathrm{~mL})$. The solution was stirred at room temperature overnight. The solvent was removed in vacuo, and the resulting powder was triturated with diethyl ether $(2 \times 2 \mathrm{~mL})$. The product was then extracted with acetonitrile $(3 \mathrm{x}$ $1 \mathrm{~mL})$, and solvent was removed in vacuo to afford the product $\left[\mathrm{NBu}_{4}\right]\left[\mathrm{Co}_{6} \mathrm{Se}_{8}(\mathrm{CN})\left(\mathrm{PEt}_{3}\right)_{5}\right](\mathbf{1 0})$ as a black powder ( $8 \mathrm{mg}, 72 \%)$. Dark crystals suitable for X-ray diffraction were grown from vapor diffusion of pentanes into a concentrated tetrahydrofuran solution.

${ }^{1} \mathrm{H}$ NMR (400 MHz, C6 $\left.\mathrm{D}_{6}, 298 \mathrm{~K}\right): \delta=3.20(\mathrm{~b}, 8 \mathrm{H}), 2.04(\mathrm{~m}, 24 \mathrm{H}), 1.95(\mathrm{~m}, 6 \mathrm{H}), 1.54(\mathrm{~b}, 8 \mathrm{H})$, $1.40(\mathrm{~b}, 8 \mathrm{H}), 1.19(\mathrm{~m}, 32 \mathrm{H}), 1.10(\mathrm{~m}, 9 \mathrm{H}), 1.01(\mathrm{~b}, 12 \mathrm{H}) \mathrm{ppm}$.

IR: $2093 \mathrm{~cm}^{-1}\left(v_{\mathrm{CN}}\right)$

Synthesis of $\quad\left[\right.$ trans-Co6 $\left.\mathrm{Ce}_{8}\left(\mathrm{C}_{5} \mathrm{H}_{5} \mathrm{~N}\right)(\mathrm{CO})\left(\mathrm{PEt}_{3}\right)_{4}\right] \quad$ (11). Freshly-prepared [trans$\left.\mathrm{Co}_{6} \mathrm{Se}_{8}\left(\mathrm{C}(\mathrm{H}) \mathrm{SiMe}_{3}\right)(\mathrm{CO})\left(\mathrm{PEt}_{3}\right)_{4}\right](6)(25 \mathrm{mg}, 0.016 \mathrm{mmol})$ was dissolved in pyridine $(1 \mathrm{~mL})$ to produce a dark red solution. The solvent was removed in vacuo to afford the product [trans$\left.\mathrm{Co}_{6} \mathrm{Se}_{8}(\mathrm{CO})\left(\mathrm{C}_{5} \mathrm{H}_{5} \mathrm{~N}\right)\left(\mathrm{PEt}_{3}\right)_{4}\right](\mathbf{1 1})$ as a black powder $(22 \mathrm{mg}, 90 \%)$. Dark crystals suitable for Xray diffraction were grown from a concentrated solution of pyridine and pentanes.

${ }^{1} \mathrm{H}$ NMR (400 MHz, C6 $\left.\mathrm{D}_{6}, 298 \mathrm{~K}\right): \delta=5.95$ (b, 2H), $4.61(\mathrm{~b}, 1 \mathrm{H}), 4.25$ (b, 2H), 1.61 (m, 24H), $0.87(\mathrm{~m}, 32 \mathrm{H}) \mathrm{ppm}$.

IR: $1958 \mathrm{~cm}^{-1}\left(\mathrm{v}_{\mathrm{CO}}\right)$

Synthesis of $\left[\right.$ trans-Co12 $\left.\mathrm{Se}_{16}(\mathrm{CO})_{2}\left(\mathrm{PEt}_{3}\right)_{8}\right][\mathrm{TCNQ}] \quad$ (12). Freshly-prepared [trans$\left.\mathrm{Co}_{6} \mathrm{Se}_{8}\left(\mathrm{C}(\mathrm{H}) \mathrm{SiMe}_{3}\right)(\mathrm{CO})\left(\mathrm{PEt}_{3}\right)_{4}\right]$ (6) $(25 \mathrm{mg}, 0.016 \mathrm{mmol}, 1 \mathrm{eq})$ was dissolved in benzene. Pyridine ( $1 \mu \mathrm{l}, 0.012 \mathrm{mmol}, 0.7 \mathrm{eq})$ was added, and the solution was stirred at room temperature overnight. A solution of tetracyanoquinodimethane (TCNQ, $1.6 \mathrm{mg}, 0.008 \mathrm{mmol}, 0.5 \mathrm{eq}$ ) in tetrahydrofuran $(5 \mathrm{~mL})$ was added to the crude mixture. The solvent was removed in vacuo, and the product was extracted from the reaction mixture with acetonitrile $(3 \times 3 \mathrm{~mL})$. The solvent was 
removed in vacuo to afford the product $\left[\right.$ trans $\left.-\mathrm{Co}_{12} \mathrm{Se}_{16}(\mathrm{CO})_{2}\left(\mathrm{PEt}_{3}\right)_{8}\right][\mathrm{TCNQ}](\mathbf{1 2})$ as a black powder (12 mg, 48\%). Dark needle-like crystals suitable for X-ray diffraction were grown from vapor diffusion of pentanes into a concentrated tetrahydrofuran solution. Similar to previously reported monocationic $\mathrm{Co}_{12} \mathrm{Se}_{16} \mathrm{~L}_{10}$ clusters, ${ }^{2,4}$ trans-Co $\left.{ }_{12} \mathrm{Se}_{16}(\mathrm{CO})_{2}\left(\mathrm{PEt}_{3}\right)_{8}\right][\mathrm{TCNQ}](\mathbf{1 2})$ is ${ }^{1} \mathrm{H}$ NMR silent.

Synthesis of $\quad\left[\right.$ trans-Co $\left.{ }_{12} \mathrm{Se}_{16}(\mathrm{CO})_{2}\left(\mathrm{PEt}_{3}\right)_{8}\right]\left[\mathrm{PF}_{6}\right] \quad$ (13). Freshly-prepared $\quad[$ trans$\left.\mathrm{Co}_{6} \mathrm{Se}_{8}\left(\mathrm{C}(\mathrm{H}) \mathrm{SiMe}_{3}\right)(\mathrm{CO})\left(\mathrm{PEt}_{3}\right)_{4}\right]$ (6) $(25 \mathrm{mg}, 0.016 \mathrm{mmol}, 1 \mathrm{eq})$ was dissolved in benzene. Pyridine $(1 \mu \mathrm{l}, 0.012 \mathrm{mmol}, 0.7 \mathrm{eq})$ was added, and the solution was stirred at room temperature overnight. The solvent was removed in vacuo. A solution of ferrocenium hexafluorophosphate (2.6 $\mathrm{mg}, 0.008 \mathrm{mmol}, 0.5 \mathrm{eq})$ in tetrahydrofuran $(5 \mathrm{~mL})$ was added to the crude mixture. The solvent was removed in vacuo, and the product was extracted from the reaction mixture with acetonitrile $(3 \times 3 \mathrm{~mL})$. The solvent was removed in vacuo, and the resulting powder was dissolved in a minimal amount of toluene, layered with ether, and let stand at $-35^{\circ} \mathrm{C}$ for three days to produce [trans- $\left.\mathrm{Co}_{12} \mathrm{Se}_{16}(\mathrm{CO})_{2}\left(\mathrm{PEt}_{3}\right)_{8}\right]\left[\mathrm{PF}_{6}\right]$ (13) as a black powder (13 mg, 52\%). Similar to previously reported $\mathrm{Co}_{12} \mathrm{Se}_{16} \mathrm{~L}_{10}$ clusters, ${ }^{2,4}$ the monocationic $\left[\right.$ trans- $\left.\mathrm{Co}_{12} \mathrm{Se}_{16}(\mathrm{CO})_{2}\left(\mathrm{PEt}_{3}\right)_{8}\right]\left[\mathrm{PF}_{6}\right](\mathbf{1 3})$ is ${ }^{1} \mathrm{H}$ NMR silent.

IR: $1954 \mathrm{~cm}^{-1}\left(v_{\mathrm{CO}}\right)$

Synthesis of $\left[\right.$ trans-Co $\left.\mathrm{Co}_{12} \mathrm{Se}_{16}\left(\mathrm{PEt}_{2}\left(p-\mathrm{C}_{6} \mathrm{H}_{4} \mathrm{SMe}\right)\right)_{2}\left(\mathrm{PEt}_{3}\right)_{8}\right]\left[\mathrm{PF}_{6}\right]$ (14). To a solution of [trans$\left.\mathrm{Co}_{12} \mathrm{Se}_{16}(\mathrm{CO})_{2}\left(\mathrm{PEt}_{3}\right)_{8}\right]\left[\mathrm{PF}_{6}\right](13)(10 \mathrm{mg}, 0.003 \mathrm{mmol}, 1 \mathrm{eq})$ was added a solution of $\mathrm{PEt}_{2}(p-$ $\left.\mathrm{C}_{6} \mathrm{H}_{4} \mathrm{SMe}\right)(1.4 \mathrm{mg}, 0.006 \mathrm{mmol}, 2 \mathrm{eq})$ in tetrahydrofuran $(3 \mathrm{~mL})$. The solution was irradiated at room temperature for three hours under blue light. The solvent was removed in vacuo to afford the product $\left[\right.$ trans $\left.-\mathrm{Co}_{12} \mathrm{Se}_{16}\left(\mathrm{PEt}_{2}\left(p-\mathrm{C}_{6} \mathrm{H}_{4} \mathrm{SMe}\right)\right)_{2}\left(\mathrm{PEt}_{3}\right)_{8}\right]\left[\mathrm{PF}_{6}\right](\mathbf{1 4})$ as a black powder $(10 \mathrm{mg}, 90 \%)$. Spectral and structural parameters were consistent with previously reported procedures. ${ }^{4}$

Synthesis of $\left[\right.$ cis- $\left.\mathrm{Co}_{12} \mathrm{Se}_{16}\left(\mathrm{PEt}_{2}\left(p-\mathrm{C}_{6} \mathrm{H}_{4} \mathrm{SMe}\right)\right)_{2}\left(\mathrm{PEt}_{3}\right)_{8}\right]\left[\mathrm{PF}_{6}\right]$ (15). To a flask loaded with a stir bar was added $60 \mathrm{mg}\left[c i s-\mathrm{Co}_{6} \mathrm{Se}_{8}\left(\mathrm{PEt}_{3}\right)_{4}(\mathrm{CO})_{2}\right](3)(0.040 \mathrm{mmol}, 1.0 \mathrm{eq})$ and $12.6 \mathrm{mg} \mathrm{PEt}_{2}(p-$ $\left.\mathrm{C}_{6} \mathrm{H}_{4} \mathrm{SMe}\right)(0.059 \mathrm{mmol}, 1.5 \mathrm{eq})$ dissolved in $6 \mathrm{~mL}$ of tetrahydrofuran. The solution was stirred under blue light at room temperature for 3 hours. The solvent was removed in vacuo to produce a mixture of the desired product $\left[c i s-\mathrm{Co}_{6} \mathrm{Se}_{8}(\mathrm{CO})\left(\mathrm{PEt}_{2}\left(p-\mathrm{C}_{6} \mathrm{H}_{4} \mathrm{SMe}\right)\right)\left(\mathrm{PEt}_{3}\right)_{4}\right]$ and byproduct $[c i s-$ $\left.\mathrm{Co}_{6} \mathrm{Se}_{8}\left(\mathrm{PEt}_{2}\left(p-\mathrm{C}_{6} \mathrm{H}_{4} \mathrm{SMe}\right)\right)_{2}\left(\mathrm{PEt}_{3}\right)_{4}\right]$ in a 1:1 mixture as determined by ${ }^{1} \mathrm{H}$ NMR spectroscopy. The crude mixture was then added to a flask loaded with a stir bar, and $6 \mathrm{~mL}$ of tetrahydrofuran was added. The solution was cooled to $-27{ }^{\circ} \mathrm{C}$, and $30 \mu \mathrm{L}$ of trimethylsilane diazomethane solution (2.0 $\mathrm{M}$ in hexanes, $0.060 \mathrm{mmol}, 1.5 \mathrm{eq}$ ) was added dropwise. The solution was stirred under blue light at $0{ }^{\circ} \mathrm{C}$ for 3 hours. The solvent was removed in vacuo to produce a mixture of the desired product $\left[c i s-\mathrm{Co}_{6} \mathrm{Se}_{8}\left(\mathrm{C}(\mathrm{H}) \mathrm{SiMe}_{3}\right)\left(\mathrm{PEt}_{2}\left(p-\mathrm{C}_{6} \mathrm{H}_{4} \mathrm{SMe}\right)\right)\left(\mathrm{PEt}_{3}\right)_{4}\right]$ along with the byproduct $[c i s-$ $\left.\mathrm{Co}_{6} \mathrm{Se}_{8}\left(\mathrm{PEt}_{2}\left(p-\mathrm{C}_{6} \mathrm{H}_{4} \mathrm{SMe}\right)\right)_{2}\left(\mathrm{PEt}_{3}\right)_{4}\right]$, which remains from the initial reaction, in what was assumed to be a 1:1 mixture (by molarity). The crude mixture was dissolved in $2 \mathrm{~mL}$ of pyridine and let sit at room temperature overnight. The solvent was removed in vacuo, and the resultant mixture was dissolved in $2 \mathrm{~mL}$ of benzene and stirred at room temperature overnight. The solvent was removed in vacuo to produce a crude mixture of the desired product [cis- $\mathrm{Co}_{12} \mathrm{Se}_{16}\left(\mathrm{PEt}_{2}(p\right.$ $\left.\left.\left.\mathrm{C}_{6} \mathrm{H}_{4} \mathrm{SMe}\right)\right)_{2}\left(\mathrm{PEt}_{3}\right)_{8}\right]$ along with the byproduct $\left[c i s-\mathrm{Co}_{6} \mathrm{Se}_{8}\left(\mathrm{PEt}_{2}\left(p-\mathrm{C}_{6} \mathrm{H}_{4} \mathrm{SMe}\right)\right)_{2}\left(\mathrm{PEt}_{3}\right)_{4}\right]$ that remains from the initial reaction to produce a total of $50 \mathrm{mg}$ of powder, which is assumed to be $33 \%$ of desired product and $66 \%$ byproduct (by molarity). The crude mixture was then added to a flask loaded with a stir bar, and a solution of $3.5 \mathrm{mg}$ of ferrocenium hexafluorophosphate $(0.011$ 
mmol, $0.27 \mathrm{eq}$ ) dissolved in $6 \mathrm{~mL}$ of tetrahydrofuran was added. The solution was stirred at room temperature overnight. The solvent was removed in vacuo, and the product was extracted from the crude mixture with acetonitrile $(3 \times 5 \mathrm{~mL})$. The solvent was removed in vacuo, and the resulting powder was dissolved in a minimal amount of toluene, layered with pentane, and let stand at -27 ${ }^{\circ} \mathrm{C}$ for three days to produce $\left[\right.$ cis- $\left.\mathrm{Co}_{12} \mathrm{Se}_{16}\left(\mathrm{PEt}_{2}\left(p-\mathrm{C}_{6} \mathrm{H}_{4} \mathrm{SMe}\right)\right)_{2}\left(\mathrm{PEt}_{3}\right)_{8}\right]\left[\mathrm{PF}_{6}\right](\mathbf{1 5})$ as a black powder (20 mg, 25\%). Dark needle-like crystals suitable for X-ray diffraction were grown from vapor diffusion of pentanes into a concentrated tetrahydrofuran solution. Similar to previously reported $\mathrm{Co}_{12} \mathrm{Se}_{16} \mathrm{~L}_{10}$ clusters, ${ }^{2,4}$ the monocationic dimer is ${ }^{1} \mathrm{H}$ NMR silent.

${ }^{1} \mathrm{H}$ NMR for intermediate $\left[c i s-\mathrm{Co}_{6} \mathrm{Se}_{8}(\mathrm{CO})\left(\mathrm{PEt}_{2}\left(p-\mathrm{C}_{6} \mathrm{H}_{4} \mathrm{SMe}\right)\right)\left(\mathrm{PEt}_{3}\right)_{4}\right]\left(500 \mathrm{MHz}, \mathrm{C}_{6} \mathrm{D}_{6}, 298 \mathrm{~K}\right)$ : $7.44(2 \mathrm{H}, \mathrm{d}), 7.06(2 \mathrm{H}, \mathrm{d}), 2.26(4 \mathrm{H}, \mathrm{m}), 1.94(3 \mathrm{H}, \mathrm{s}), 1.79(12 \mathrm{H}$, quin $), 1.73(12 \mathrm{H}$, quin $), 1.00$ $(18 \mathrm{H}, \mathrm{m}), 0.99(6 \mathrm{H}, \mathrm{m}), \delta=0.96(18 \mathrm{H}, \mathrm{m}) \mathrm{ppm}$.

Single crystal X-ray diffraction. Data for all compounds was collected on an Agilent SuperNova diffractometer using mirror-monochromated $\mathrm{Cu}$ or $\mathrm{Mo}$ Ka radiation. Data collection, integration, scaling (ABSPACK) and absorption correction (face-indexed Gaussian integration) ${ }^{5}$ were performed in CrysAlisPro. ${ }^{6}$ Structure solution was performed using ShelXT. ${ }^{7}$ Subsequent refinement was performed by full-matrix least-squares on $F_{2}$ in ShelXL. $3{ }^{8}$ Olex2 was used for viewing and to prepare CIF files. ${ }^{9}$ Thermal ellipsoid plots were prepared in CrystalMaker. ${ }^{10}$ Thermal ellipsoids are rendered at the 50\% probability level and shown in Figures S1-S5.

We note that in 15, the crystal quality was quite low. With the given data, the connectivity can be accurately assessed, but other information such as ligand bond distances or angles, cannot accurately be determined. We have included the crystallographic information for completeness. We note that all conclusions made in the main text rely exclusively on the connectivity.

Cyclic voltammetry. Cyclic voltammetry was collected using a BioLogic VSP-300 potentiostat in an $\mathrm{N}_{2}$-filled glovebox. The measurements were collected in a $0.1 \mathrm{M}$ solution of tetrabutylammonium hexafluorophosphate supporting electrolyte in tetrahydrofuran, using a glassy carbon working electrode, a platinum wire counter electrode, and a silver wire pseudoreference electrode, with a scan speed of $50 \mathrm{mV} / \mathrm{s}$. All measurements were then referenced to the ferrocene/ferrocenium redox couple.

Computational chemistry. All quantum chemical calculations were performed using Jaguar, version 9.5, Schrodinger, Inc., New York, NY, 2017. ${ }^{11}$ All calculations were done using density functional theory, using the B3LYP-D3 functional and 6-31g**/LACVP** basis sets for the light/heavy atoms, respectively. The geometries of all of the molecules referred to in the text were optimized, and geometrical coordinates will be provided upon request. In each of the molecules studied trimethylphosphine $\left(\mathrm{P}\left(\mathrm{CH}_{3}\right)_{3}\right)$ was used as the two-electron donor ligand rather than

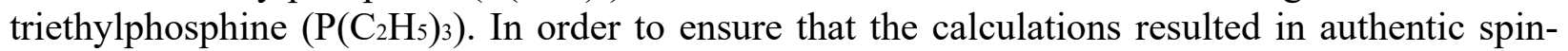
states, spin-restricted methods were used throughout. 


\section{Supplementary Figures}
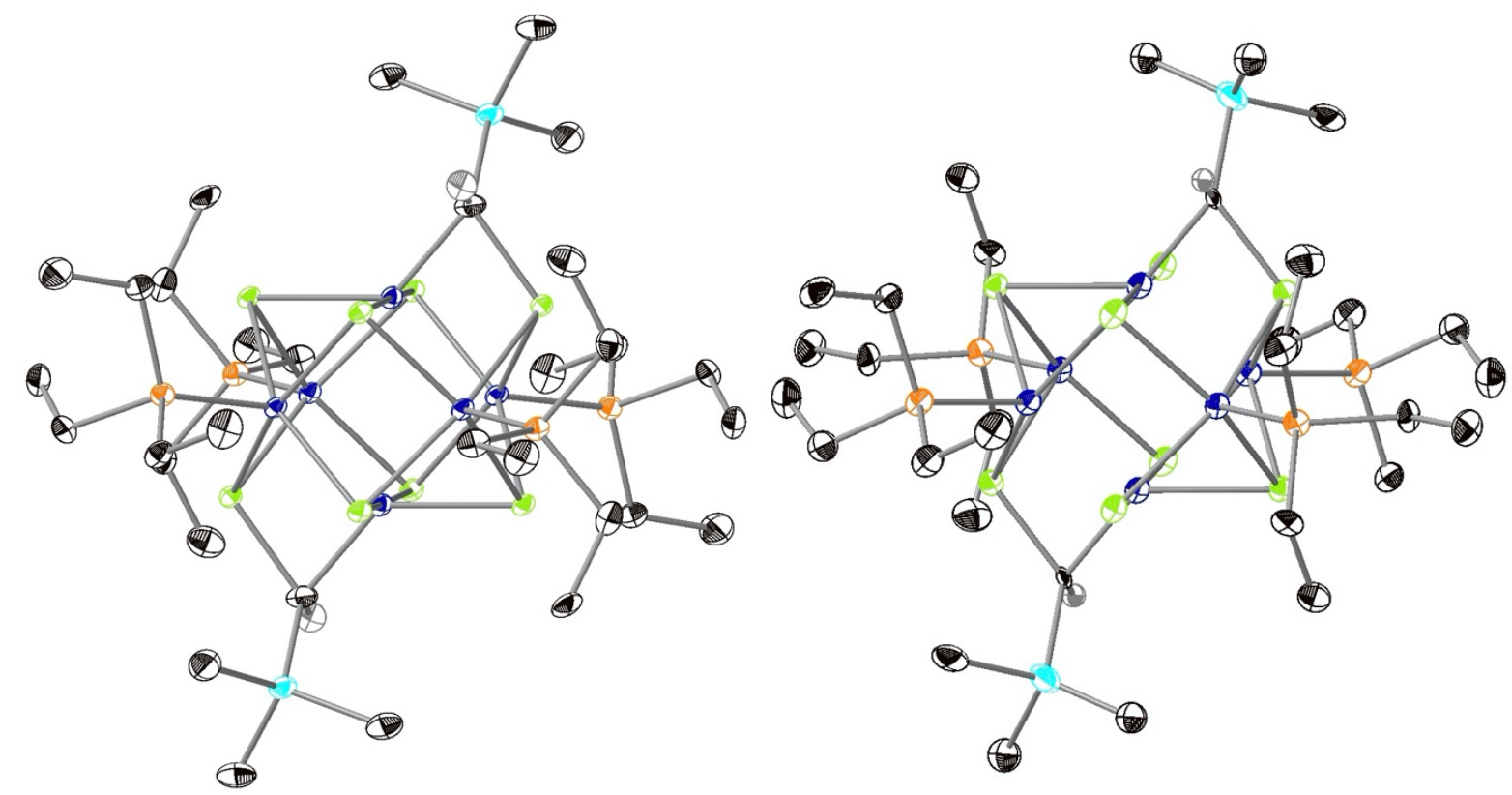

Figure S1. Molecular structures of the two independent molecules of trans$\left[\mathrm{Co}_{6} \mathrm{Se}_{8}\left(\mathrm{C}(\mathrm{H}) \mathrm{SiMe}_{3}\right)_{2}\left(\mathrm{PEt}_{3}\right)_{4}\right]$ (5) shown with ellipsoids at 50\% probability. Each independent position has one-half cluster in the asymmetric unit. Disordered solvent, select hydrogen atoms, and the minor positions of disordered ligands are omitted for clarity. Black, carbon; grey, hydrogen; blue, cobalt; orange, phosphorus; green, selenium; teal, silicon.

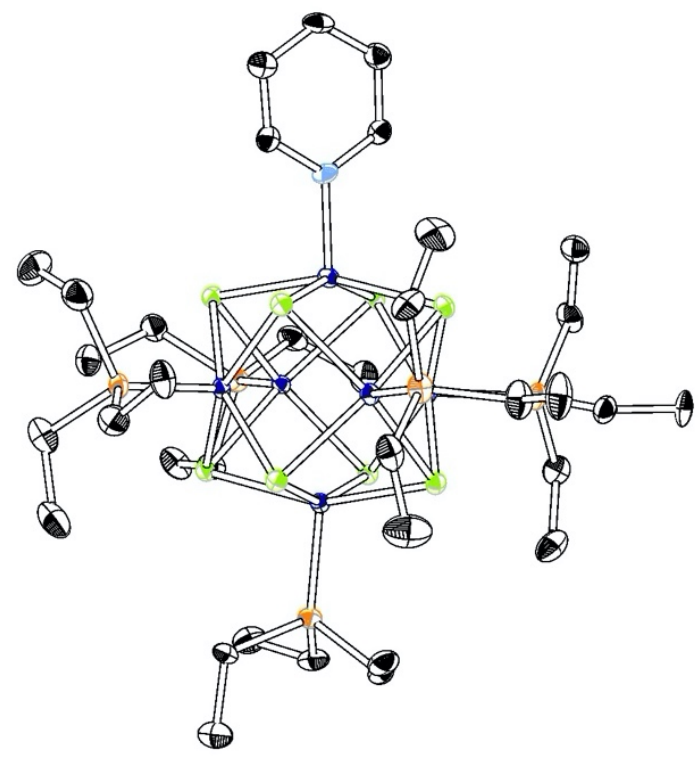

Figure S2. Molecular structure of $\left[\mathrm{Co}_{6} \mathrm{Se}_{8}\left(\mathrm{C}_{5} \mathrm{H}_{5} \mathrm{~N}\right)\left(\mathrm{PEt}_{3}\right)_{5}\right](8)$ shown with ellipsoids at 50\% probability. Disordered solvent, hydrogen atoms, and the minor positions of disordered ligands are omitted for clarity. Black, carbon; dark blue, cobalt; light blue, nitrogen; orange, phosphorus; green, selenium. 


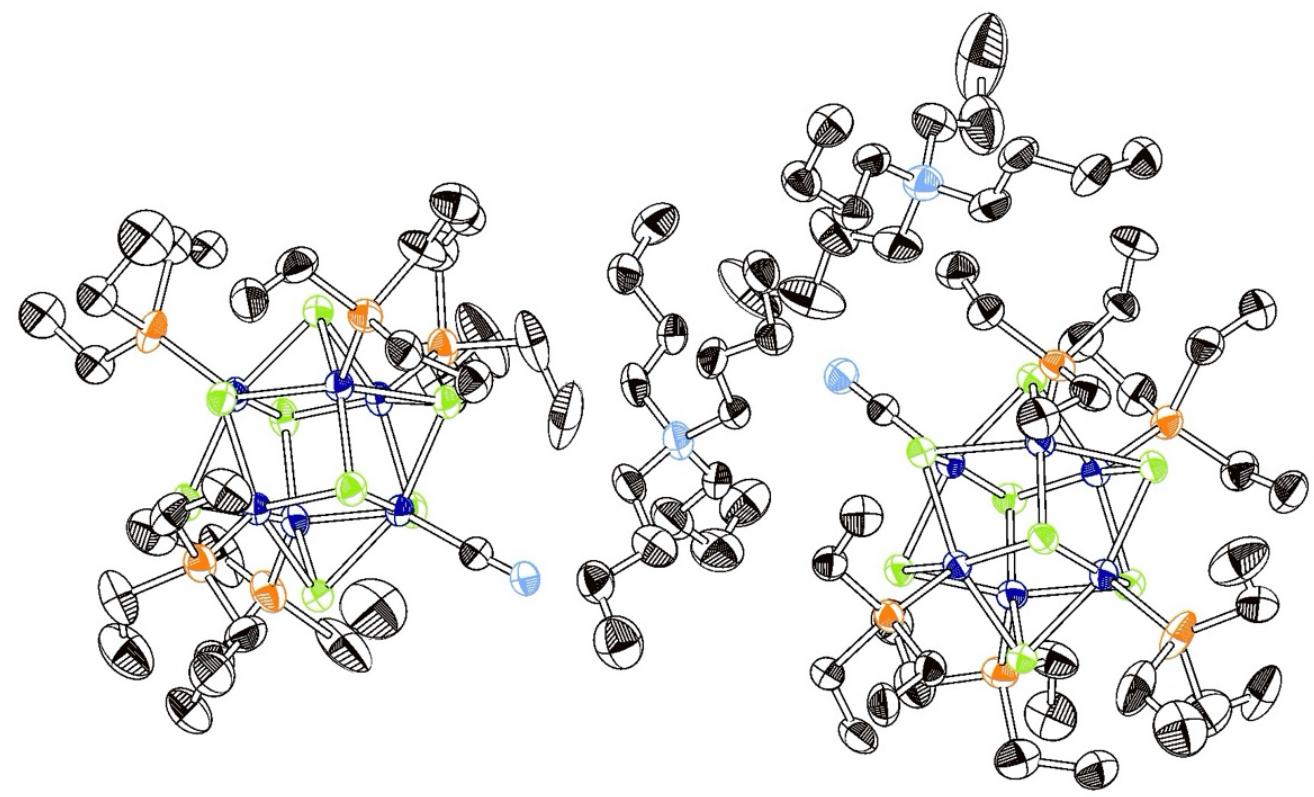

Figure S3. Molecular structures of the two independent molecules of $[\mathrm{NBu} 4]\left[\mathrm{Co}_{6} \mathrm{Se}_{8}(\mathrm{CN})\left(\mathrm{PEt}_{3}\right)_{5}\right]$ (10) shown with ellipsoids at 50\% probability. Disordered solvent, hydrogen atoms, and the minor positions of disordered ligands are omitted for clarity. Black, carbon; dark blue, cobalt; light blue, nitrogen; orange, phosphorus; green, selenium.

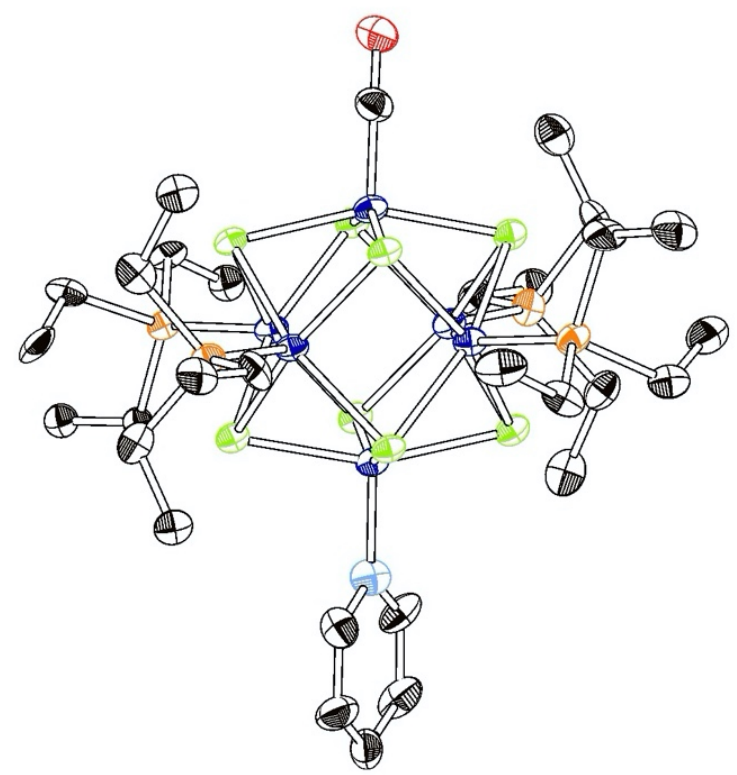

Figure S4. Molecular structure of $\left[\right.$ trans $\left.-\mathrm{Co}_{6} \mathrm{Se}_{8}\left(\mathrm{C}_{5} \mathrm{H}_{5} \mathrm{~N}\right)(\mathrm{CO})\left(\mathrm{PEt}_{3}\right)_{4}\right](\mathbf{1 1})$ shown with ellipsoids at $50 \%$ probability. Disordered solvent, hydrogen atoms, and the minor positions of disordered ligands are omitted for clarity. Black, carbon; dark blue, cobalt; light blue, nitrogen; red, oxygen; orange, phosphorus; green, selenium. 

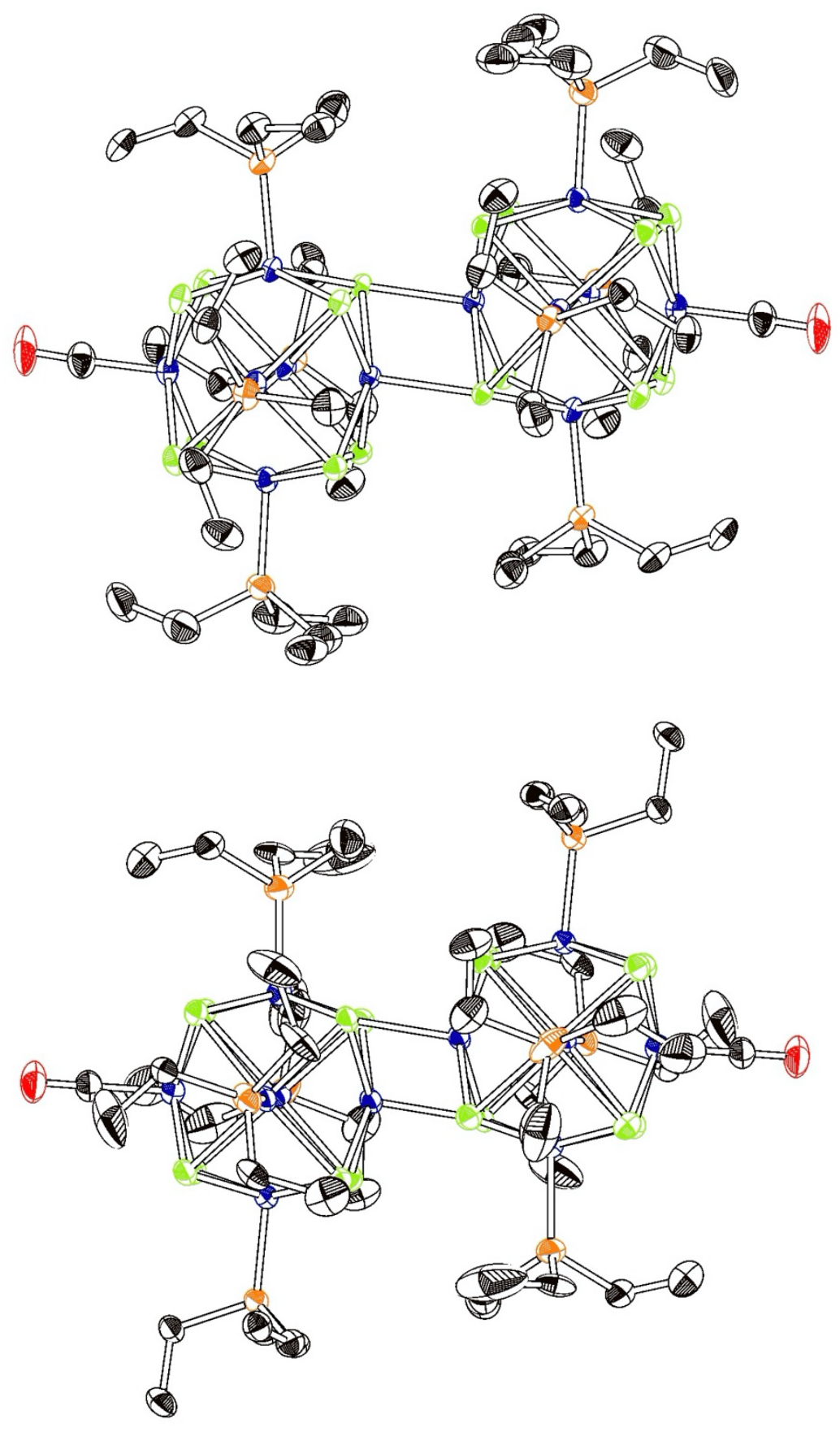

Figure S5. Molecular structures of the two independent molecules of [trans$\left.\mathrm{Co}_{12} \mathrm{Se}_{16}(\mathrm{CO})_{2}\left(\mathrm{PEt}_{3}\right)_{8}\right][\mathrm{TCNQ}]$ (12) shown with ellipsoids at 50\% probability. Each independent position has one-half cluster in the asymmetric unit. Disordered solvent, hydrogen atoms, and the minor positions of disordered ligands are omitted for clarity. Black, carbon; dark blue, cobalt; red, oxygen; orange, phosphorus; green, selenium. 


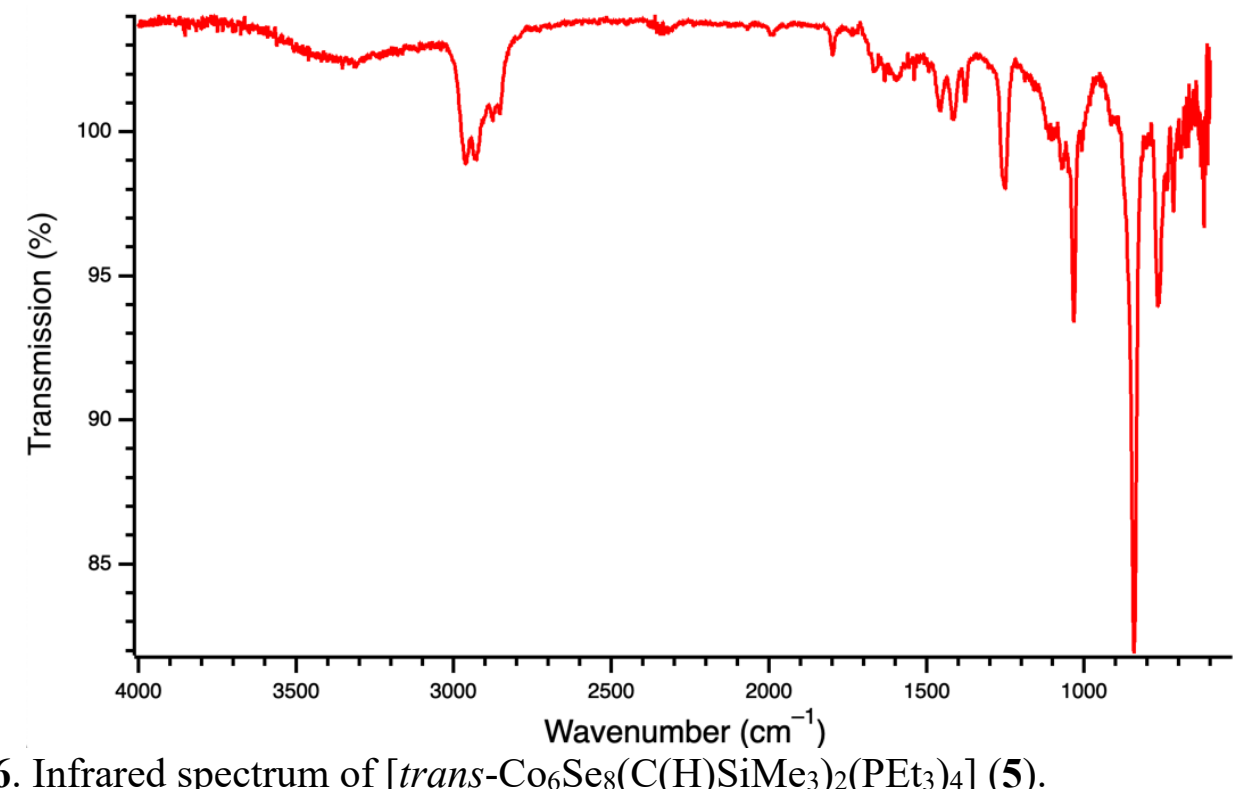

Figure S6. Infrared spectrum of $\left[\right.$ trans $\left.-\mathrm{Co}_{6} \mathrm{Se}_{8}\left(\mathrm{C}(\mathrm{H}) \mathrm{SiMe}_{3}\right)_{2}\left(\mathrm{PEt}_{3}\right)_{4}\right](\mathbf{5})$. 


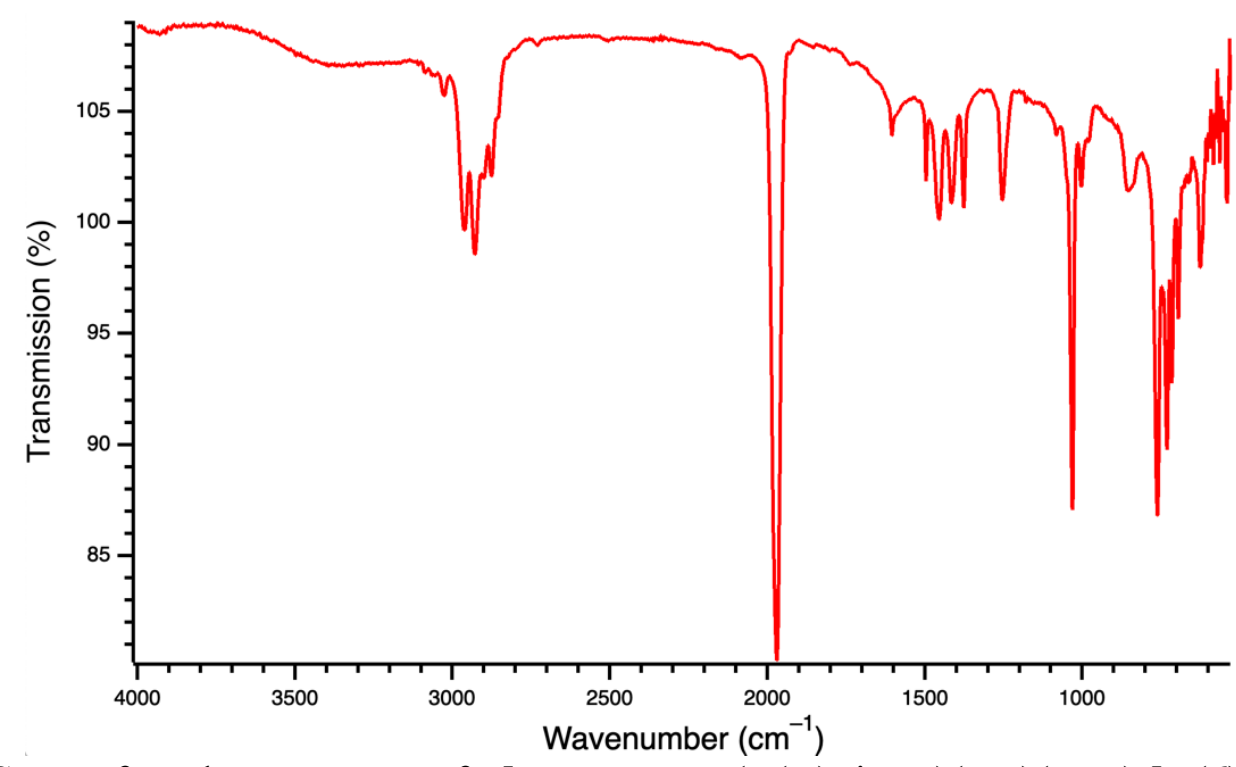

Figure S7. Infrared spectrum of $\left[\right.$ trans $\left.-\mathrm{Co}_{6} \mathrm{Se}_{8}\left(\mathrm{C}(\mathrm{H}) \mathrm{SiMe}_{3}\right)(\mathrm{CO})\left(\mathrm{PEt}_{3}\right)_{4}\right]$ (6). The peak corresponding to the $\mathrm{CO}$ group is at $1969 \mathrm{~cm}^{-1}$.

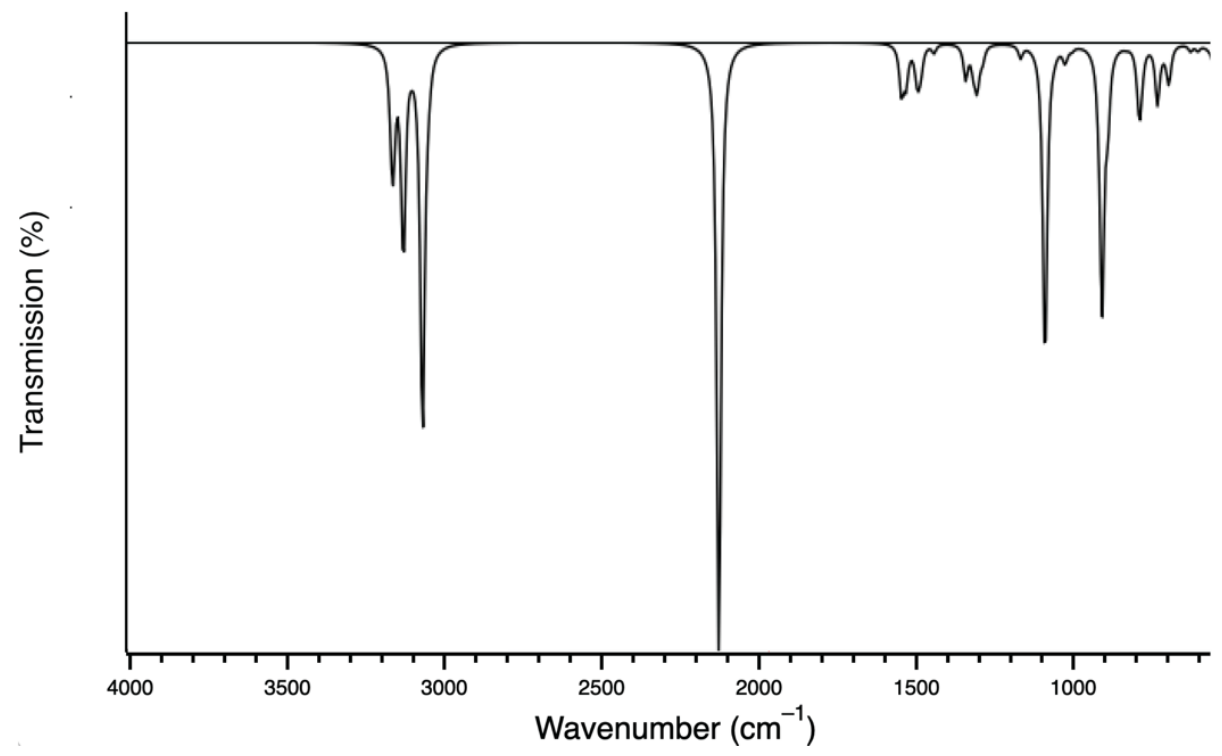

Figure S8. Predicted infrared spectrum of $\left[\right.$ trans $\left.-\mathrm{Co}_{6} \mathrm{Se}_{8}\left(\mathrm{C}(\mathrm{H}) \mathrm{SiMe}_{3}\right)(\mathrm{CO})\left(\mathrm{PEt}_{3}\right)_{4}\right](\mathbf{6})$ determined using structure shown in Figure 1d. The major features qualitatively match those seen in the experimentally determined spectra in Figure S7, with all major features consistently blueshifted. Note that experimentally determined values for features such as C-H stretches centered at 2900 $\mathrm{cm}^{-1}$ and the CO stretch centered at $1969 \mathrm{~cm}^{-1}$ in Figure S7 are consistent with previously reported values. $^{1}$ 


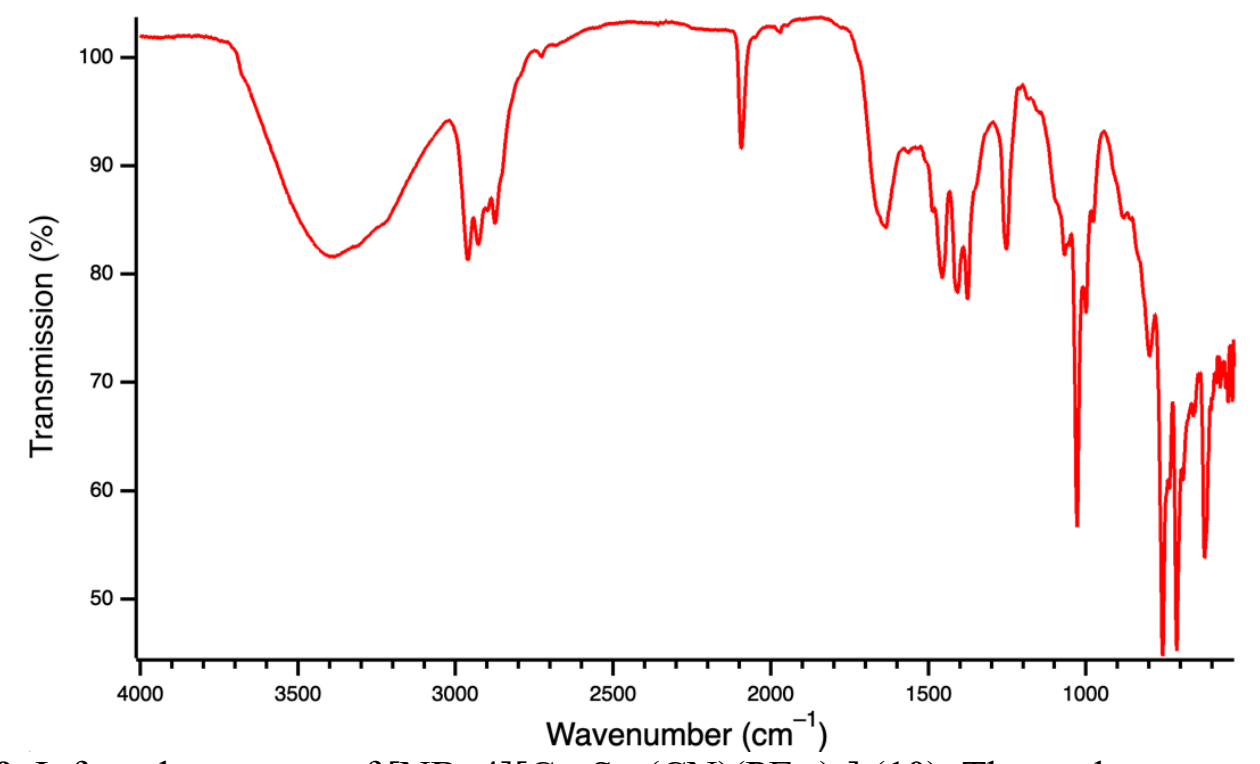

Figure S9. Infrared spectrum of $[\mathrm{NBu} 4]\left[\mathrm{Co}_{6} \mathrm{Se}_{8}(\mathrm{CN})\left(\mathrm{PEt}_{3}\right)_{5}\right](\mathbf{1 0})$. The peak corresponding to the $\mathrm{CN}$ group is at $2093 \mathrm{~cm}^{-1}$.

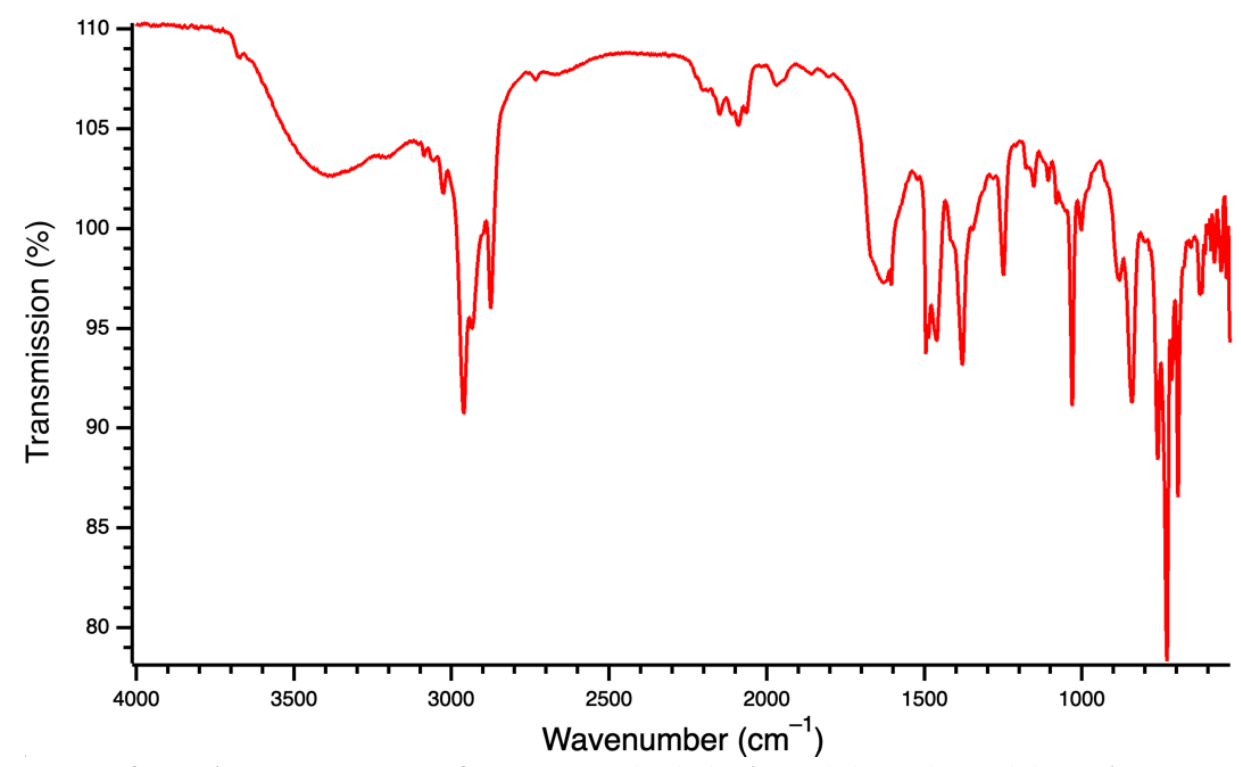

Figure S10. Infrared spectrum of $\left[\mathrm{Co}_{6} \mathrm{Se}_{8}\left(\mathrm{C}(\mathrm{H}) \mathrm{SiMe}_{3}\right)\left(\mathrm{PEt}_{3}\right)_{5}\right]$ (4) when reacted with a substoichiometric amount of tetrabutylammonium cyanide. The multiple peaks corresponding to $\mathrm{CN}$ groups $\left(2000-2200 \mathrm{~cm}^{-1}\right)$ indicates degradation of the cluster under these experimental conditions. 


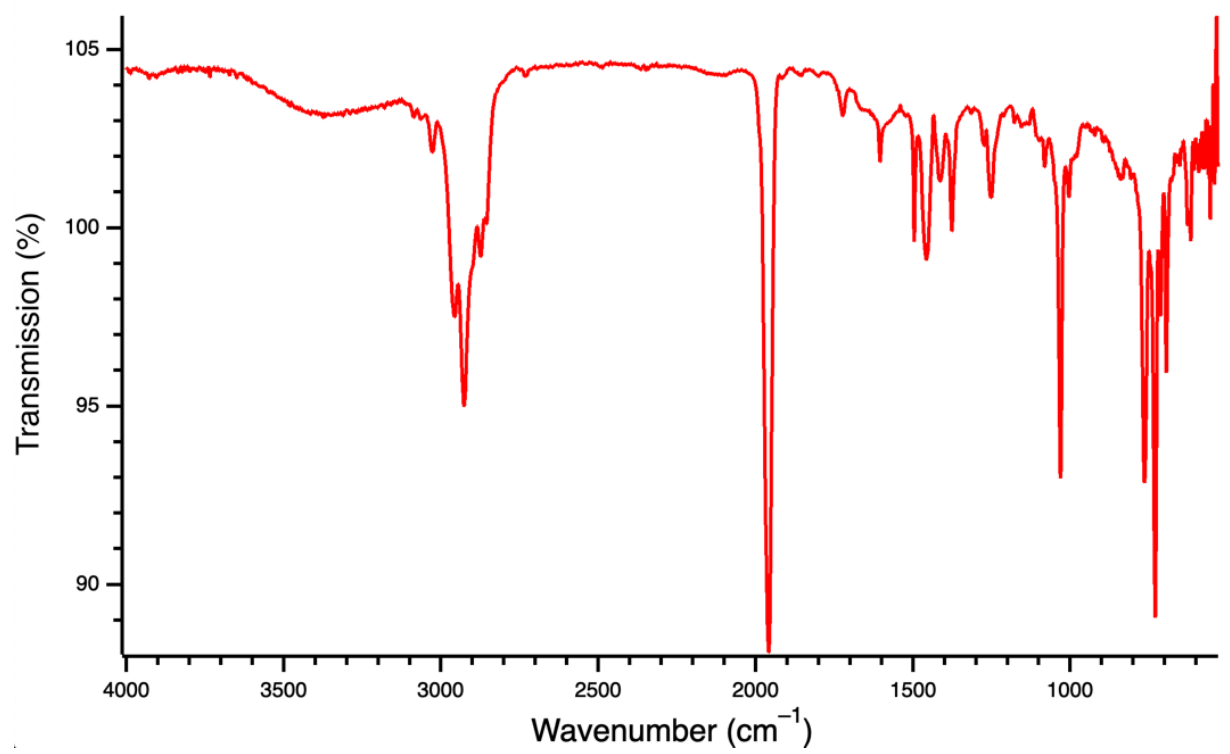

Figure S11. Infrared spectrum of $\left[\right.$ trans $\left.-\mathrm{Co}_{6} \mathrm{Se}_{8}\left(\mathrm{C}_{5} \mathrm{H}_{5} \mathrm{~N}\right)(\mathrm{CO})\left(\mathrm{PEt}_{3}\right)_{4}\right]$ (11). The peak corresponding to the $\mathrm{CO}$ group is at $1958 \mathrm{~cm}^{-1}$.

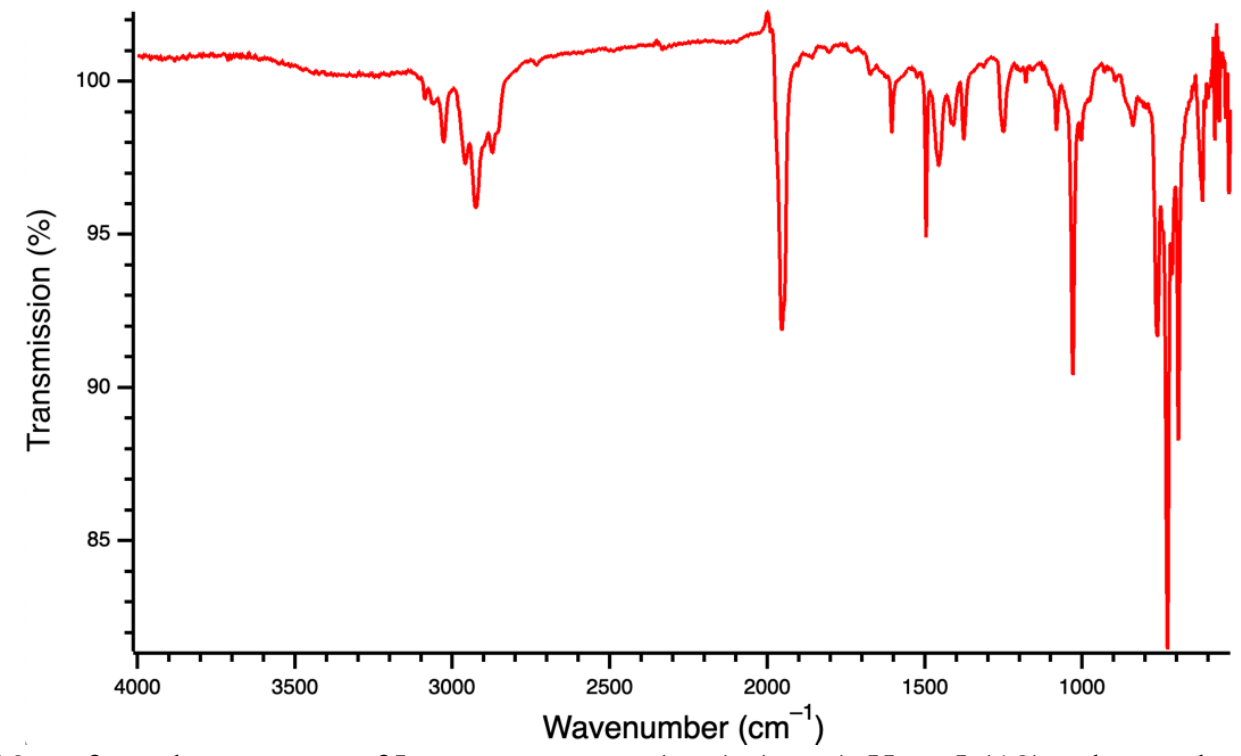

Figure S12. Infrared spectrum of $\left[\right.$ trans $\left.-\mathrm{Co}_{12} \mathrm{Se}_{16}(\mathrm{CO})_{2}\left(\mathrm{PEt}_{3}\right)_{8}\right]\left[\mathrm{PF}_{6}\right](\mathbf{1 3})$. The peak corresponding to the CO group is at $1954 \mathrm{~cm}^{-1}$. 


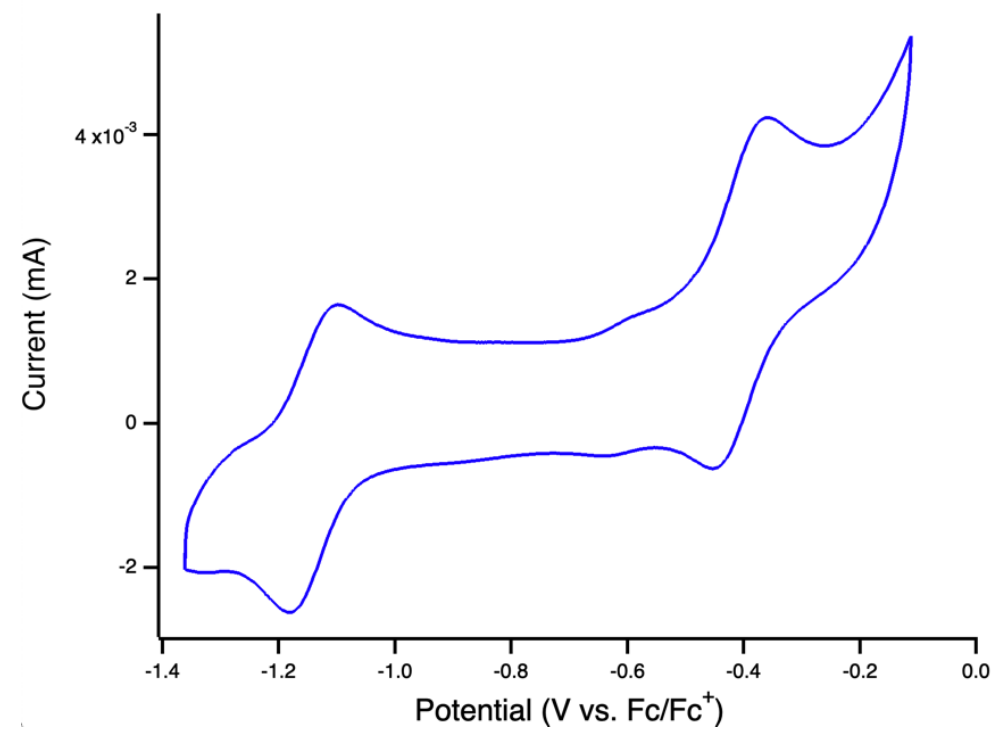

Figure S13. Cyclic voltammogram of $[\mathrm{NBu} 4]\left[\mathrm{Co}_{6} \mathrm{Se}_{8}(\mathrm{CN})\left(\mathrm{PEt}_{3}\right)_{5}\right](\mathbf{1 0})$, collected in a $0.1 \mathrm{M}$ tetrabutylammonium hexafluorophosphate solution in tetrahydrofuran at a scan rate of $50 \mathrm{mV} / \mathrm{s}$.

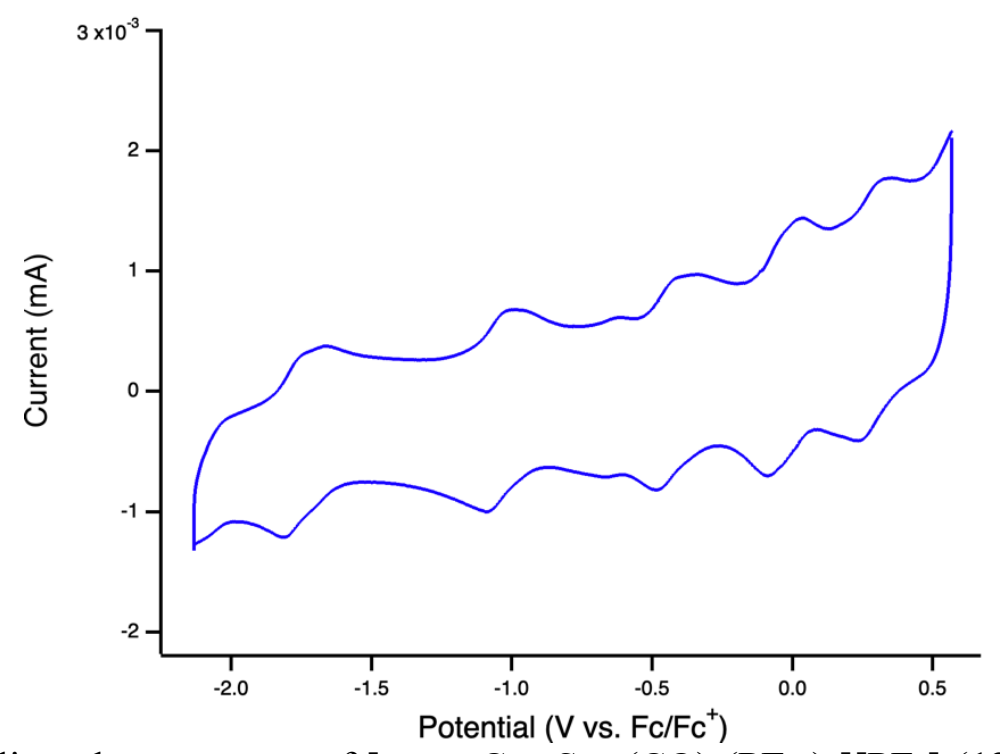

Figure S14. Cyclic voltammogram of $\left[\right.$ trans $\left.-\mathrm{Co}_{12} \mathrm{Se}_{16}(\mathrm{CO})_{2}\left(\mathrm{PEt}_{3}\right)_{8}\right]\left[\mathrm{PF}_{6}\right](\mathbf{1 3})$, collected in a 0.1 $\mathrm{M}$ tetrabutylammonium hexafluorophosphate solution in tetrahydrofuran at a scan rate of $50 \mathrm{mV} / \mathrm{s}$. 


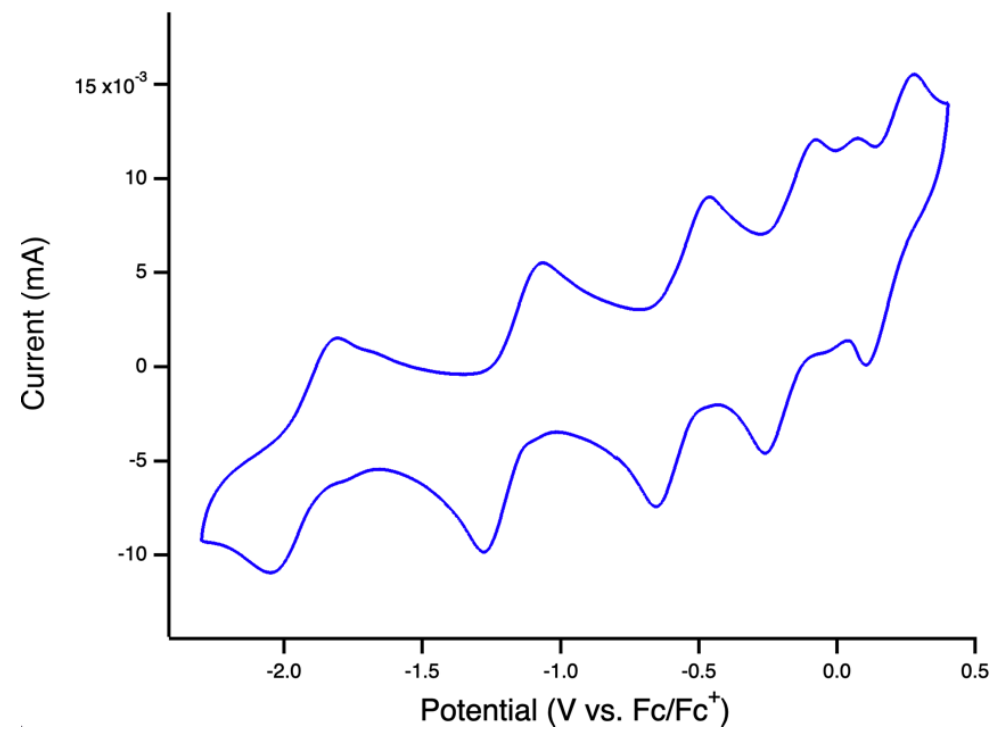

Figure S15. Cyclic voltammogram of $\left[c i s-\mathrm{Co}_{12} \mathrm{Se}_{16}\left(\mathrm{PEt}_{2}\left(p-\mathrm{C}_{6} \mathrm{H}_{4} \mathrm{SMe}\right)\right)_{2}\left(\mathrm{PEt}_{3}\right)_{8}\right]\left[\mathrm{PF}_{6}\right]$ (15), collected in a $0.1 \mathrm{M}$ tetrabutylammonium hexafluorophosphate solution in tetrahydrofuran at a scan rate of $50 \mathrm{mV} / \mathrm{s}$. Feature centered at $0 \mathrm{~V}$ corresponds to residual ferrocene or ferrocenium impurity used during the synthesis. 


\section{Supplementary Tables}

\begin{tabular}{|c|c|c|c|}
\hline $\begin{array}{l}\text { Name } \\
\text { CSD Code } \\
\text { Crystal System } \\
\text { Space Group } \\
\text { Temperature (K) }\end{array}$ & $\begin{array}{l}{\left[\text { trans-Co}{ }_{6} \mathrm{Se}_{8}\left(\mathrm{C}(\mathrm{H}) \mathrm{SiMe}_{3}\right)_{2}\left(\mathrm{PEt}_{3}\right)_{4}\right]} \\
\mathbf{( 5 )} \\
2110276 \\
\text { Triclinic } \\
P-1 \\
100(1)\end{array}$ & $\begin{array}{l}{\left[\mathrm{Co}_{6} \mathrm{Se}_{8}\left(\mathrm{C}_{5} \mathrm{H}_{5} \mathbf{N}\right)\left(\mathrm{PEt}_{3}\right)_{5}\right]} \\
(8) \\
2110279 \\
\text { Monoclinic } \\
P 2_{1} / \mathrm{c} \\
100(1)\end{array}$ & $\begin{array}{l}{\left[\mathrm{NBu}_{4}\right]\left[\mathrm{Co}_{6} \mathrm{Se}_{8}(\mathrm{CN})\left(\mathrm{PEt}_{3}\right)_{5}\right]} \\
(10) \\
2110277 \\
\text { Triclinic } \\
P-1 \\
100(1)\end{array}$ \\
\hline $\begin{array}{l}a(\AA) \\
b(\AA) \\
c(\AA) \\
\alpha\left(\left(^{\circ}\right)\right. \\
\beta\left(^{\circ}\right) \\
y\left(^{\circ}\right) \\
V\left(\AA^{3}\right) \\
Z \\
\text { Radiation } \\
\text { Crystal Size } \\
(\mathrm{mm})\end{array}$ & $\begin{array}{l}13.1659(5) \\
15.3519(6) \\
15.3771(7) \\
91.006(3) \\
109.873(4) \\
97.778(3) \\
2889.4(2) \\
2 \\
\text { Mo Ka } \\
0.24 \times 0.19 \times 0.08\end{array}$ & $\begin{array}{l}11.5583(3) \\
11.8706(4) \\
38.7985(10) \\
90 \\
93.796(2) \\
90 \\
5311.6(3) \\
1 \\
\text { Cu Ka } \\
0.10 \times 0.07 \times 0.05\end{array}$ & $\begin{array}{l}13.9916(4) \\
22.2299(7) \\
24.0145(7) \\
66.772(3) \\
79.799(3) \\
89.914(3) \\
6736.0(4) \\
2 \\
\text { Cu Ka } \\
0.19 \times 0.03 \times 0.02\end{array}$ \\
\hline $\begin{array}{l}\text { Diffractometer } \\
\text { Measured } \\
\text { Reflections }\end{array}$ & $\begin{array}{l}\text { SuperNova } \\
26430\end{array}$ & $\begin{array}{l}\text { SuperNova } \\
72545\end{array}$ & $\begin{array}{l}\text { SuperNova } \\
88693\end{array}$ \\
\hline $\begin{array}{l}\text { Independent } \\
\text { Reflections }\end{array}$ & 13590 & 10584 & 26701 \\
\hline $\begin{array}{l}\text { Observed } \\
\text { Reflections } \\
R_{1} / w R_{2} \\
R_{\text {int }}\end{array}$ & $\begin{array}{l}10547 \\
0.048 / 0.101 \\
0.046\end{array}$ & $\begin{array}{l}0.057 / 0.163 \\
0.149\end{array}$ & $\begin{array}{l}16653 \\
0.074 / 0.214 \\
0.120\end{array}$ \\
\hline
\end{tabular}

\begin{tabular}{l|lll}
$\boldsymbol{R}_{\text {int }}$ & 0.046 & 0.149 & 0.120
\end{tabular}

\begin{tabular}{|c|c|}
\hline $\begin{array}{l}\text { Name } \\
\text { CSD Code } \\
\text { Crystal System } \\
\text { Space Group } \\
\text { Temperature (K) }\end{array}$ & $\begin{array}{l}{\left[\text { trans }-\mathrm{Co}_{6} \mathrm{Se}_{8}\left(\mathrm{C}_{5} \mathrm{H}_{5} \mathrm{~N}\right)(\mathrm{CO})\left(\mathrm{PEt}_{3}\right)_{4}\right]} \\
(11) \\
2110280 \\
\text { Monoclinic } \\
P 2_{1} / n \\
100(1)\end{array}$ \\
\hline $\begin{array}{l}a(\AA) \\
b(\AA) \\
c(\AA) \\
\alpha\left(\left(^{\circ}\right)\right. \\
\beta\left({ }^{\circ}\right) \\
Y\left({ }^{\circ}\right) \\
V\left(\left(^{3}\right)\right. \\
Z \\
\text { Radiation } \\
\text { Crystal Size } \\
\text { (mm) } \\
\text { Diffractometer } \\
\text { Measured } \\
\text { Reflections } \\
\text { Independent } \\
\text { Reflections } \\
\text { Observed } \\
\text { Reflections } \\
R_{1} / \text { wR } \\
R_{2}\end{array}$ & $\begin{array}{l}12.6800(7) \\
23.8326(16) \\
15.6966(14) \\
90 \\
92.522(6) \\
90 \\
4738.9(6) \\
4 \\
\text { Cu Ka } \\
0.17 \times 0.02 \times 0.01 \\
\text { SuperNova } \\
47944 \\
9445 \\
5052 \\
0.084 / 0.208 \\
0.231\end{array}$ \\
\hline
\end{tabular}

[trans-Co ${ }_{12} \mathrm{Se}_{16}(\mathrm{CO})_{2}\left(\mathrm{PEt}_{3}\right)_{8}$ ] [TCNQ] (12)

2110278

Triclinic

P-1

$100(1)$

$14.3258(2)$

$17.2703(3)$

19.4179(3)

90.9372(14)

92.6497(13)

91.0680(15)

4797.50(14)

2

$\mathrm{Cu} \mathrm{Ka}$

$0.20 \times 0.16 \times 0.04$

SuperNova

63747

18969

16607

$0.039 / 0.097$

0.046

$\left[c i s-\mathrm{Co}_{12} \mathrm{Se}_{16}\left(\mathrm{PEt}_{2}\left(\boldsymbol{p}-\mathrm{C}_{6} \mathrm{H}_{4} \mathrm{SMe}\right)\right)_{2}\left(\mathrm{PEt}_{3}\right)_{8}\right]$
$\left[\mathrm{PF}_{6}\right](15)$
2111707
Triclinic
$P-1$
$100(1)$
$13.7555(12)$
$15.3851(15)$
$16.0148(16)$
$113.419(10)$
$102.641(9)$
$98.627(8)$
$2926.4(6)$
2
Cu Ka
$0.23 \times 0.07 \times 0.03$
SuperNova
22788
7149
3761
$0.086 / 0.284$
0.104




\section{References:}

(1) Champsaur, A. M.; Velian, A.; Paley, D. W.; Choi, B.; Roy, X.; Steigerwald, M. L.; Nuckolls, C. Building Diatomic and Triatomic Superatom Molecules. Nano Lett. 2016, 16 (8), 5273-5277.

(2) Champsaur, A. M.; Hochuli, T. J.; Paley, D. W.; Nuckolls, C.; Steigerwald, M. L. Superatom Fusion and the Nature of Quantum Confinement. Nano Lett. 2018, 18 (7), 4564-4569.

(3) Roy, X.; Schenck, C. L.; Ahn, S.; Lalancette, R. A.; Venkataraman, L.; Nuckolls, C.; Steigerwald, M. L. Quantum Soldering of Individual Quantum Dots. Angew. Chem. Int. Ed. 2012, 51 (50), 12473-12476.

(4) Gunasekaran, S.; Reed, D. A.; Paley, D. W.; Bartholomew, A. K.; Venkataraman, L.; Steigerwald, M. L.; Roy, X.; Nuckolls, C. Single-Electron Currents in Designer SingleCluster Devices. J. Am. Chem. Soc. 2020, 142 (35), 14924-14932.

(5) Blanc, E.; Schwarzenbach, D.; Flack, H. D. The Evaluation of Transmission Factors and Their 1st Derivatives with Respect to Crystal Shape-Parameters. J. Appl. Crystallogr. 1991, 24, 1035-1041.

(6) Version 1.171.37.35 (2014). Oxford Diffraction /Agilent Technologies UK Ltd, Yarnton, England.

(7) Sheldrick, G. M. SHELXT - Integrated space-group and crystal-structure determination. Acta Crystallogr. A 2015, 71, 3-8.

(8) Sheldrick, G. M. Crystal structure refinement with SHELXL. Acta Crystallogr. C 2015, $71,3-8$.

(9) Dolomanov, O. V.; Bourhis, L. J.; Gildea, R. J.; Howard, J. A. K.; Puschmann, H. OLEX2: a complete structure solution, refinement and analysis program. J. Appl. Crystallogr. 2009, 42, 339-341.

(10) CrystalMaker Software Ltd. Oxford, England: www.crystalmaker.com.

(11) Bochevarov, A. D.; Harder, E.; Hughes, T. F.; Greenwood, J. R.; Braden, D. A.; Philipp, D. M.; Rinaldo, D.; Halls, M. D.; Zhang, J.; Friesner, R. A. Jaguar: A high-performance quantum chemistry software program with strengths in life and materials sciences. Int. J. Quantum. Chem. 2013, 113, 2110-2142. 